\title{
Growth Stress in Peltophorum dubium and its Correlation with the Growth Variables
}

\author{
Carolina Nogueira Xavier ${ }^{1}$, Carlos Eduardo Silveira da Silva ${ }^{2}$, \\ Pablo Vieira dos Santos ${ }^{2}$, Alexandre Monteiro de Carvalho ${ }^{2}$, \\ Alexandre Miguel do Nascimento ${ }^{2}$, Pedro Henrique Santin Brancalion ${ }^{3}$ \\ ${ }^{1}$ Departamento de Ciências Florestais, Universidade Federal de Lavras - UFLA, Lavras/MG, Brazil \\ ${ }^{2}$ Departamento de Produtos Florestais, Universidade Federal Rural do Rio de Janeiro - UFRRJ, Seropédica/RJ, Brazil \\ ${ }^{3}$ Departamento de Ciências Florestais, Escola Superior de Agricultura "Luiz de Queiroz" - ESALQ, Universidade de São \\ Paulo - USP, Piracicaba/SP, Brazil
}

\begin{abstract}
The exploitation of valuable native timber species in forest restoration projects has emerged as a promising strategy to make restoration financially viable. There are few studies regarding the quality of timber from restoration plantations. The aim of this study was to analyze growth stresses by determining the longitudinal residual strain (LRS) and evaluate their correlation with the growth variables in the species Peltophorum dubium (Spreng.) Taub in a 14-year old restoration plantation. Eighteen individuals were evaluated, determining the following variables: diameter at breast height (DBH), bark thickness, average annual growth in diameter (IMA) and annual periodic growth in diameter (IPA ${ }_{2012-2015}$ ). The LRS was determined by the extensometer (CIRAD-Forêt), on DBH height and in the north-south direction of each tree. The LRS average was $0.072 \mathrm{~mm}$, within the range of expected wood values for sawmilling. There was a significant positive correlation between the LRS, DBH and IMA.
\end{abstract}

Keywords: extensometer, canafístula, increase in diameter. 


\section{INTRODUCTION}

The restoration of degraded forest ecosystems and landscapes has emerged as a promising strategy to face the global environmental crisis that has threatened human wellbeing and biodiversity conservation (Suding et al., 2015; Chazdon et al., 2016). In Brazil, ambitious restoration programs, such as the Atlantic Forest Restoration Pact (Melo et al., 2013), and legal requirements to restore a total of 21 million hectares of native ecosystems in private landholdings according to the Native Vegetation Protection Law (Brancalion et al., 2016), are examples of national scale initiatives. However, high implementation costs and negligible economic returns for farmers have limited the expansion of restoration programs. In the case of tropical forests, the exploitation of valuable native timber species in forest restoration projects has emerged as a promising strategy to make restoration financially viable (Brancalion et al., 2012; Lamb et al., 2005), but little is known about the quality of the timber from restoration plantations.

The main factor that decreases income for sawmills during timber processing is the occurrence of top cracks and warping observed in the wood after felling, which compromises the quality of the wood, contributing to the depreciation of the value of the material and limits its use in a lumber production. These effects are caused by growth stresses (Trugilho et al., 2006). Growth stresses are natural forces acting on the tissues of the trees that are intended to support and stabilize the trunk (Lima et al., 2004). These mechanical stresses are generated during tree growth in response to environmental (light, wind and slope) and silvicultural (thinning, pruning and density) (Souza, 2002) agents. They are in balance when the tree is standing, but when it is cut, deformations and cracks in the tops of the trunks occur immediately as a result of the steady state modification that existed during growth (Ferrand, 1983). In this context, it is necessary to study this phenomenon in order to assess its relationship with tree growth, and thus try to minimize its effects, leading to improved product quality, adding value and increasing competitiveness (Rocha \& Tomaselli, 2002).
The most widely used method for indirect evaluation of growth stresses is the extensometer (Trugilho, 2005). This method was developed by the Centre de Recherche Agronomique in Cooperation Internationale Pour Le Développement - CIRAD-Fôret. Due to its easy use, speed of data collection in the field and the reliability of results, the method has been used for genetic studies and selection of eucalyptus clones (Souza, 2002; Pádua et al., 2004; Trugilho et al., 2006; Rodrigues et al., 2008). Studies relating longitudinal residual strain (LRS) with wood splitting indices, aiming at increasing the quality of the wood and the yield for log sawing also use this tool (Lima et al., 2013; Beltrame et al., 2015; Silva et al., 2016). However, LRS has mostly been assessed with an extensometer in Eucalyptus trees, which limits the reliability of its use for species with other characteristics, including many native valuable timber species.

The use of non-destructive methods of timber quality evaluation, such as extensometer to measure LRS, would be particularly important to assess timber quality in cultivated native trees because most of the old mixed plantations, when estimating the silvicultural potential of native trees (Silva, 2013), are located in Areas of Permanent Protection, where cutting trees is not allowed.

One of the most promising native trees for timber production in plantations is the canafístula tree (Peltophorum dubium - Fabaceae), which produces high quality timber in native forests and productivity of $19.60 \mathrm{~m}^{3} / \mathrm{ha} /$ year in plantations (Revista da Madeira, 2007). In Ruchel (2003) studies on the evolution of the use and utilization of timber species, the deciduous forest of the Upper Uruguay ranked canafístula amongst the eight highest priority species for lumber. However, there is no information about the quality of canafístula trees in plantations. In this sense, scientific studies that aimed to boost the measurement variables and the relationship between the forestry and timber industries becomes necessary (Mendonça, 2006).

Therefore, the objective of this study was to determine the longitudinal residual strain as an indicator of growing stresses and analyze their correlation with the growth variables of 14-year old canafístula trees in a restoration plantation. 


\section{MATERIAL AND METHODS}

\subsection{Study sites and species}

Peltophorum dubium is a native tree popularly known as canafístula, which belongs to the legume family (Fabaceae) and subfamily Caesalpinioideae, has extensive natural occurrence, from the state of Bahia to Rio Grande do Sul, often found in semi-deciduous forests (Carvalho, 2003). The species have fast growing and is considered secondary initial (Durigan \& Nogueira, 1990), but with pioneering characteristics (Marchiori, 1997), being abundant in secondary formations, but with few individuals, usually with large proportions, occupying the dominant strata of the canopy of primary forest. It plays a pioneering role in open areas, roosts and degraded forests. (Carvalho, 2003). We sampled 18 canafístula trees in a 14-year old restoration plantation established in a farm located in the municipality of Descalvado - SP ( $21^{\circ} 54^{\prime} 14^{\prime \prime} \mathrm{S}$ and $\left.47^{\circ} 37^{\prime} 12^{\prime \prime} \mathrm{W}\right)$, at $685 \mathrm{~m}$ of altitude (Cidade-Brasil, 2016). According to the climatic classification of Koeppen, the municipality is classified as Cwa, with an average temperature of $21.4^{\circ} \mathrm{C}$ and average rainfall of $1508.7 \mathrm{~mm}$, characterized as having a rainy summer, with average rainfall of $211 \mathrm{~mm}$ and dry winter, with average of $31.8 \mathrm{~mm}$ (CEPAGRI, 2016). The study area, was a mixed plantation of approximately 100 native species, spaced $3 \mathrm{~m} \times 2 \mathrm{~m}$ without fertilization.

\subsection{Measurements}

The evaluated growth variables were the diameter at breast height $(\mathrm{DBH})$, the mean annual increment (MAI) and the periodic annual diameter growth in the 3-years $\left(\mathrm{IPA}_{2012-2015}\right)$. The circumference at breast height $(\mathrm{CBH}), 1.30 \mathrm{~m}$ above the ground, was obtained using a tape measure; then, the data was transformed into $\mathrm{DBH}$.

To evaluate the growth of the species, we calculated the mean annual growth (MAI), dividing the DBH by tree age, and annual periodic growth in diameter (IPA $\left.{ }_{2012-2015}\right)$ from two measurements: for the years 2012 and 2015. The data from 2012 was obtained from the research conducted by Silva (2013), and we used the same trees, which had been individually tagged and geo-referenced. Equation 1 was used to calculate the IPA ${ }_{2012-2100^{*}}$.

$$
I P A_{2012-2015}=\frac{d f-d i}{P}
$$

legend: $\mathrm{IPA}_{2012-2015}=$ Annual diameter growth (cm / year); $\mathrm{df}=\mathrm{DBH}$ evaluated at the end of the growth period $(\mathrm{cm}) ; \mathrm{di}=\mathrm{DBH}$ evaluated early in the growth period $(\mathrm{cm}) ; \mathrm{P}=$ measured range (years)

The LRS measurements were performed on living trees through the extensometer device, developed by the Centre de Recherche Agronomique in Cooperation Internationale Pour Le Développement - CIRAD-Fôret. When conducting the test, a portion of the tree bark was initially removed and at this time, the thickness of the bark was measured using a digital caliper with a precision of $0.01 \mathrm{~mm}$. A window of rectangular shape measuring approximately $8 \mathrm{~cm} \times 20 \mathrm{~cm}$ was made by removing bark,, to fix two metal pins, at a distance of $45 \mathrm{~mm}$, arranged along the longitudinal direction of the trunk. Subsequently, the extensometer was supported on the upper pin and its dial indicator reset. Then a hole was made between the metal pins with the aid of a bow drill (hand drill) with a $20 \mathrm{~mm}$ drill bit. After drilling, the inner tension of the tree was released and recorded using an indicator clock. Measurements of longitudinal residual strain (LRS) were performed at the time of DBH being collected by tree along the north-south direction. The measurements were performed with no wind, as the air movement causes the internal support forces to oscillate the tree and consequently oscillates the clock display, which impairs reading.

\section{RESULTS AND DISCUSSION}

The average observed in the growth in diameter (Table 1) in this study was within the range expected for the age studied (14 years) compared with data from the literature. In prior research, the average diameter growth for canafístula of different ages was $1.83 \mathrm{~cm} /$ year (at age 8) (Costa et al., 2010); $0.70 \mathrm{~cm} /$ year (to 12.9 years) (Ferreira et al., 2007); $0.86 \mathrm{~cm} /$ year (to 24 years) (Senna et al., 2012); $0.96 \mathrm{~cm} /$ year (to 11 years) (Sebbenn et al., 1999). Gurgel (1975) noted that the growth of canafístula at 7 years is intense, observing that 2-year old canafístula trees had a diameter growth of $2.40 \mathrm{~cm} /$ year. From 21-years old the value decreased to $0.90 \mathrm{~cm} /$ year.

Diameter growth generally tends to be greater during the first years following planting and drops over time and with the development of the tree (Senna et al., 2012). 
This fact was observed in this study by comparing the IPA $_{2012-2015}$ and MAI values (Table 1), where growth over the last three years, represented by the IPA ${ }_{2012-2015}$ was lower than the average annual increase (MAI) based on the age of the tree. Therefore, there is a very high growth rate for the diameter of canafistula, especially during early years of growth, decreasing over the course of time but still considered as rapidly growing.

The average LRS $(0.072 \mathrm{~mm})$ found for Peltophorum dubium (Table 1) was close to those values obtained when working with Eucalyptus clones and higher than well-known hardwood species. The lower the LRS rate, the lower the propensity to cracking, improving the quality of wood for timber and therefore raising the market value of the wood. The mean LRS of Eucalyptus clones for different ages ( $3,5,7,8$ and 9 ) was $0.065 \mathrm{~mm}$ (Cardoso et al., 2005); $0.076 \mathrm{~mm}$; to $7.6 ; 4.3$ and 4 years (Pádua et al., 2004); $0.071 \mathrm{~mm}$ to $8.5 ; 11$ and 15 (Lima et al., 2004); to 10.5 years of age, LRS ranged from 0.066 to $0.125 \mathrm{~mm}$ (Trugilho et al., 2006). For other hardwood species, the average value of the canafistula LRS was superior in comparison with Teak trees (Tectona grandis L. F.) at 14 years of age that showed an average LRS of $0.047 \mathrm{~mm}$ (Flórez, 2012). The Australian cedar (Toona ciliata) at 2 and 5 years old has an average LRS of $0.056 \mathrm{~mm}$ (Gonçalves, 2009). The LRS in black wattle trees (Acacia mearnsii), at 4 and 7 years old, was $0.066 \mathrm{~mm}$ (Delucis et al., 2015).
The difference in behavior of the growth stresses between species is normal, suggesting that these can be controlled by genetic factors (Chafe, 1979). Lima et al. (2004) demonstrated that the LRS varied as a function of genetic material into five Eucalyptus clones. Trugilho et al. (2006) and Pádua et al. (2004) found the high heritability of LRS in Eucalyptus clones, concluding that this feature has a strong genetic control.

The average value found for the LRS of canafistula was lower than that obtained by Silva et al. (2016) for two species of African mahogany at 19 years of age, Khaya ivorensis $(0.082 \mathrm{~mm})$ and Khaya senegalensis $(0.084 \mathrm{~mm})$. The authors found positive but not significant relationships, between the indices of top cracking of logs and LRS. They also concluded that the values permits the use and quality of African mahogany for the production of lumber. In this sense, compared with the LRS found in this study, canafistula wood has the potential to produce lumber and shows potential for use in timber production as well as making tropical forest restoration economically viable.

A positive and significant correlation between the DBH and LRS $(r=0.471)$ (Figure 1$)$ and between LRS and MAI $(r=0.471)$ was observed. No significant correlation between the LRS and other variables was observed (Table 2).

Table 1. Average DBH, LRS, bark thickness and diameter growth for 18 canafístula trees.

\begin{tabular}{lccccc} 
& $\begin{array}{c}\text { DBH } \\
(\mathbf{c m})\end{array}$ & $\begin{array}{c}\text { LRS } \\
(\mathbf{m m})\end{array}$ & $\begin{array}{c}\text { Bark thickness } \\
(\mathbf{m m})\end{array}$ & $\begin{array}{c}\text { IPA }_{\text {2012-2015 }} \\
(\mathbf{c m} / \text { year })\end{array}$ & $\begin{array}{c}\text { MAI } \\
(\mathbf{c m} / \text { year })\end{array}$ \\
\hline Average & 23.74 & 0.072 & 6.99 & 1.09 & 1.70 \\
Minimum & 12.80 & 0.025 & 4.56 & 0.01 & 0.91 \\
Maximum & 44.56 & 0.135 & 10.49 & 2.68 & 3.18 \\
S & 10.92 & 0.037 & 1.43 & 0.84 & 0.78 \\
CV $(\%)$ & 45.99 & 51.097 & 20.42 & 77.04 & 45.99 \\
\hline
\end{tabular}

Legend: DBH: diameter at breast height $(1.30 \mathrm{~m})$; LRS: longitudinal residual strain; IPA ${ }_{2012-2015}$ : regular annual diameter growth during the period 2012-2015; MAI: average annual growth; S: standard deviation; CV: coefficient of variation (\%).

Table 2. Pearson correlation between DBH, LRS, bark thickness and diameter growth.

\begin{tabular}{lccccc} 
& $\begin{array}{c}\text { DBH } \\
(\mathbf{c m})\end{array}$ & $\begin{array}{c}\text { LRS } \\
(\mathbf{m m})\end{array}$ & $\begin{array}{c}\text { Bark thickness } \\
(\mathbf{m m})\end{array}$ & $\begin{array}{c}\text { IPA }_{2012-2015} \\
(\mathbf{c m} / \text { year })\end{array}$ & MAI (cm/year) \\
DBH $(\mathrm{cm})$ & 1 & $0.471^{*}$ & $0.396^{\mathrm{ns}}$ & $0.689^{*}$ & 1 \\
LRS (mm) & 1 & $0.139^{\mathrm{ns}}$ & $0.206^{\mathrm{ns}}$ & $0.471^{*}$ \\
Bark thickness $(\mathrm{cm})$ & & & 1 & $0.301^{\mathrm{ns}}$ & $0.396^{\mathrm{ns}}$ \\
IPA $_{2012-2015}(\mathrm{~cm} /$ year) & & & & 1 & $0.689^{*}$ \\
MAI (cm/year) & & & & 1 \\
\hline
\end{tabular}

Legend: DBH: diameter at breast height $(1.30 \mathrm{~m})$; LRS: longitudinal residual deformation; IPA ${ }_{2012-2015}$ : periodic annual growth in diameter in the period 2012-2015; MAI: average annual increment; ${ }^{\star} 5 \%$ significance; ${ }^{\mathrm{ns}}$ no significant. 


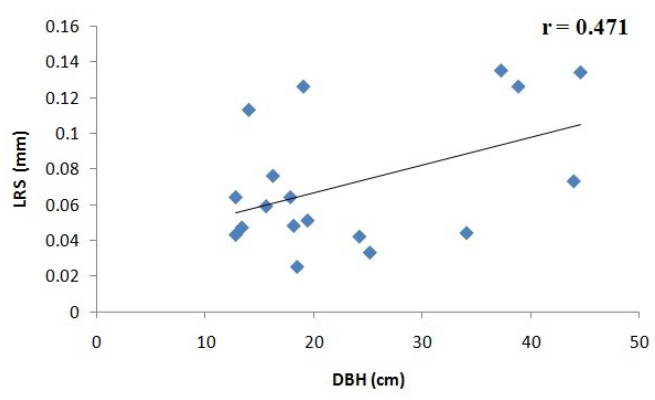

Figure 1. Correlation between DBH and LRS.

Malan \& Hoon (1992), in research with Eucalyptus spp., observed a significant correlation between the average annual increase in the diameter of the living trees and cracks in the tops in trunks.

Vidaurre et al. (2015) analyzing the Eucalyptus benthamii at 5 years of age, found a correlation of 0.368 between the maximum LRS and DBH values. Muneri et al. (2000) studied Eucalyptus cloeziana at 4 years of age finding a significant correlation with LRS and DBH $(r=0.51)$.

On the other hand, some studies have shown a significant negative correlation between the $\mathrm{DBH}$ and the LRS in Eucalyptus (Trugilho et al., 2004; Silva, 2008; Carvalho et al., 2010; Delucis et al., 2015).

The LRS is influenced by growth factors which, depending on the species, may have a negative or positive impact.

The causes of growth stress levels are not well understood, although there is strong evidence that they are linked to the genotype, age, size of the trunk, growth rate and inclination of trunks (Rech \& Silva, 2001).

This study noted that for 14-year old canafistula trees, the growth rate is a factor which influences the LRS, the higher growth causes largest increases of LRS. It was found that for IPA ${ }_{2012-2015}$, the growth decreased over a period of three years. (Table 1) Therefore, there was no significant correlation between LRS and diameter growth over the last 3 years (IPA $2012-2015$ ) (Table 2).

The LRS tends to be lower for canafístula trees when its growth rate diminishes, a phenomenon related to tree age. According to Rech \& Silva (2001) the internal tensions have greater intensity in younger trees, considerably reducing maturation. Based on this information, we can minimize the effects of growing stresses using silvicultural treatments, or plan the cutting of trees at an older age, to increase the quality and value of canafístula wood.

\section{CONCLUSIONS}

For the LRS of the canafístula trees evaluated in this study, the age of 14 years was close to the values observed in Eucalyptus clones. In this respect, when compared with other species used in the timber industry, canafistula wood has the potential to produce lumber.

The growth variables, DBH and MAI showed significant and positive correlations in relation to LRS.

The evaluation of the LRS and growth variables in canafistula trees older than those analyzed is recommended.

\section{SUBMISSION STATUS}

Received: 31 may, 2016

Accepted: 22 feb., 2017

\section{CORRESPONDENCE TO}

\section{Carolina Nogueira Xavier}

Departamento de Ciências Florestais,

Universidade Federal de Lavras - UFLA,

Campus Universitário, CP 3037, CEP 37200-000,

Lavras, MG, Brazil

e-mail: ncarolx@gmail.com

\section{REFERENCES}

Beltrame R, Peres ML, Lazarotto M, Gatto DA, Schneid E, Haselein CR. Tensão de crescimento e sua relação com as rachaduras de topo em toras de Eucalyptus spp. Scientia Forestalis 2015; 43(105): 63-74.

Brancalion PHS, Garcia LC, Loyola R, Rodrigues RR, Pillar VD, Lewinsohn TM. A critical analysis of the Native Vegetation Protection Law of Brazil (2012): updates and ongoing initiatives. Natureza \& Conservação 2016; 14(Suppl 1): 1-15. http://dx.doi.org/10.1016/j.ncon.2016.03.003.

Brancalion PHS, Viani RAG, Strassburg BBN, Rodrigues RR. Finding the money for tropical forest restoration. Unasylva 2012; 63(239): 41-50.

Cardoso AA Jr, Trugilho PF, Lima JT, Rosado SC. S., Mendes LM. Deformação residual longitudinal em diferentes espaçamentos e idades em clone de híbrido de Eucalyptus. Cerne 2005; 11(3): 218-224.

Carvalho AM, Gonçalves MPM, Amparado KF, Latorraca JVF, Garcia RA. Correlações da altura e diâmetro com as tensões de crescimento em árvores de Corymbia citriodora 
e Eucalyptus urophylla. Revista Árvore 2010; 34(2): 323-331. http://dx.doi.org/10.1590/S0100-67622010000200015.

Carvalho PER. Espécies arbóreas brasileiras. Vol. 1. Brasília: Embrapa Informação Tecnológica; 2003. 1039 p.

Centro de Pesquisas Meteorológicas e Climáticas Aplicadas à Agricultura - CEPAGRI. Clima dos Municípios Paulistas. Campinas: CEPAGRI; 2016. [cited 2016 Jan 30]. Available from: http://www.cpa.unicamp.br/outras-informacoes/ clima_muni_153.html

Chafe SC. Growth stresses in trees. Australian Forest Research 1979; 9: 203-223.

Chazdon RL, Brancalion PHS, Laestadius L, BennettCurry A, Buckingham K, Kumar C et al. When is a forest a forest? Forest concepts and definitions in the era of forest and landscape restoration. Ambio 2016; 45(5): 538-550. PMid:26961011. http://dx.doi.org/10.1007/ s13280-016-0772-y.

Cidade-Brasil. Munícipio de Descalvado. Descalvado: Cidade-Brasil; 2016. [cited 2016 Jan 30]. Available from: http://www.cidade-brasil.com.br/municipio-descalvado.html

Costa MP, Nappo ME, Caçador FRD, Barros HHD. Avaliação do processo de reabilitação de um trecho de floresta ciliar na bacia do rio Itapemirim - ES. Revista Árvore 2010; 34(5): 835-851. http://dx.doi.org/10.1590/ S0100-67622010000500009.

Delucis RA, Beltrame R, Gatto DA, Cademartori PHG, Schneid E. Análise da deformação residual longitudinal e sua relação com propriedades tecnológicas da madeira de acácia-negra. Revista Árvore 2015; 39(3): 585-594. http:// dx.doi.org/10.1590/0100-67622015000300020.

Durigan G, Nogueira JCB. Recomposição de matas ciliares. São Paulo: Instituto Florestal; 1990. 14 p. (IF Série Registros; no. 4).

Ferrand JC. Growth stresses and silviculture of eucalyptus. Australian Forest Research 1983; 13(1): 75-81.

Ferreira WC, Botelho SA, Davide AC, Faria JMR. Avaliação do crescimento do estrato arbóreo de área degradada revegetada à margem do Rio Grande, na Usina Hidrelétrica de Camargos, MG. Revista Árvore 2007; 31(1): 177-185. http://dx.doi.org/10.1590/S0100-67622007000100020.

Flórez JM. Caracterização tecnológica da madeira jovem de teca (Tectona grandis L. f) [dissertation]. Lavras: Universidade Federal de Lavras; 2012.

Gonçalves SVB. Ferramentas para a avaliação das propriedades da madeira em Árvores vivas de Toona ciliata (Roemer) e aplicações no melhoramento genético [dissertation]. Lavras: Universidade Federal de Lavras; 2009.

Gurgel OA. Fo. Essências indígenas. Silvicultura 1975; 9: 47-52.

Lamb D, Erskine PD, Parrotta JA. Restoration of degraded tropical forest landscapes. Science 2005; 310(5754):
1628-1632. PMid:16339437. http://dx.doi.org/10.1126/ science. 1111773 .

Lima IL, Freitas JA, Garcia JN. Influência da classe diamétrica nos índices de rachadura da madeira em Liquidambar styraciflua. Floresta e Ambiente 2013; 20(1): 117-123. http://dx.doi.org/10.4322/floram.2012.064.

Lima JT, Trugilho PF, Rosado SCS, Cruz CR. Deformações residuais longitudinais decorrentes de tensões de crescimento em eucaliptos e suas associações com outras propriedades. Revista Árvore 2004; 28(1): 107-116. http:// dx.doi.org/10.1590/S0100-67622004000100014.

Malan FS, Hoon M. Effect of initial spacing and thinning on some wood properties of Eucalyptus grandis. South African Forestry Journal 1992; 163(1): 13-20. http://dx.doi. org/10.1080/00382167.1992.9629362.

Marchiori JNC. Dendrologia das angiospermas: leguminosas. Santa Maria: Editora UFSM; 1997.

Melo FPL, Pinto SRR, Brancalion PHS, Castro PS, Rodrigues RR, Aronson J et al. Priority setting for scalingup tropical forest restoration projects: Early lessons from the Atlantic Forest Restoration Pact. Environmental Science \& Policy 2013; 33: 395-404. http://dx.doi.org/10.1016/j. envsci.2013.07.013.

Mendonça AR. Avaliação de uma metodologia para otimização do volume de toras comerciais de Eucalyptus sp. em função da qualidade do fuste [dissertation] Alegre: Universidade Federal do Espírito Santo; 2006.

Muneri A, Knight J, Legate W, Palmer G. Relationships between surface longitudinal growth strain and tree size, wood properties and timber distortion of 4 year old plantation grown Eucalyptus cloeziana. In: Proceedings of I Ufro Conference: the future of eucalypts for wood products; 2000; Launceston, Austrália. Launceston: IUFRO; 2000. p. 292-300.

Pádua FA, Trugilho PF, Rosado SCS, Lima JT, Cardoso Júnior AA, de Oliveira AC. Estimativa de parâmetros genéticos das tensões de crescimento em clones de Eucalyptus. Scientia Forestalis 2004; 66: 152-160.

Rech C, Silva JC. Características intrínsecas da madeira. Revista da Madeira 2001; 10: 60-65.

Revista da Madeira. Espécies tropicais promissoras. Revista da Madeira 2007; 18(108): 98-106.

Rocha MP, Tomaselli I. Efeito do modelo de desdobro na qualidade da madeira serrada de Eucalyptus grandis e Eucalyptus dunnii. Cerne 2002; 8(2): 70-83.

Rodrigues EDC, Rosado SCD, Trugilho PF, Santos AM. Seleção de clones de Eucalyptus para as proriedades físicas da madeira avaliadas em árvores no campo. Cerne 2008; 14(2): 147-152.

Ruchel AR. Evolução do uso e valorização das espécies madeiráveis da Floresta Estacional Decidual do alto Uruguai. Ciência Florestal 2003; 13(1): 153-166. 
Sebbenn AM, Siqueira ACMF, Vencovsky R, Machado JAR. Interação genótipo $\mathrm{x}$ ambiente na conservação ex situ de Peltophorum dubium, em duas regiões do Estado de São Paulo. Revista Instituto Florestal 1999; 11(1): 75-89.

Senna SN, Freitas MLM, Zanatto ACS, Morais E, Zanata M, Moraes MLT et al. Variação e parâmetros genéticos em teste de progênies de polinização livre de Peltophorum dubium (Sprengel) taubert em Luiz Antonio-SP. Scientia Forestalis 2012; 40(95): 345-352.

Silva LD. Melhoramento genético de Eucalyptus benthamii Maiden et Cambage visando a produção de madeira serrada em áreas de ocorrência de geadas severas [thesis]. Curitiba: Setor de Ciências Agrárias, Universidade Federal do Paraná; 2008.

Silva CC. Potencial de espécies nativas para a produção de madeira serrada em plantios de restauração florestal. [dissertation]. Piracicaba: Escola Superior de Agricultura “Luiz de Queiroz", Universidade de São Paulo; 2013.

Silva JGM, Vidaurre GB, Arantes MDC, Batista DC, Soranso DR, Billo DF. Qualidade da madeira de mogno africano para a produção de serrados. Scientia Forestalis 2016; 44(109): 181-190. http://dx.doi.org/10.18671/scifor. v44n 109.18 .

Souza MAM. Deformação Residual Longitudinal (DRL) causada pelas tensões de crescimento em clones de híbridos de Eucalyptus [dissertation]. Lavras: Universidade Federal de Lavras; 2002.

Suding KN, Farrer EC, King AJ, Kueppers L, Spasojevic MJ. Vegetation change at high elevation: scale-dependence and interactive effects on Niwot Ridge. Plant Ecology \& Diversity 2015; 8(5-6): 713-725. http://dx.doi.org/10.10 80/17550874.2015.1010189.

Trugilho PF. Tensão de crescimento em árvores vivas de clones de Eucalyptus spp. e de Eucalyptus dunnii Maiden e propriedades de sua madeira [thesis]. Curitiba: Universidade Federal do Paraná; 2005

Trugilho PF, Iwakiri S, Rocha MP, Matos JLM, Saldanha LK. Efeitos da idade e classe diamétrica na deformação residual longitudinal em árvores de Eucalyptus dunnii Maiden. Revista Árvore 2004; 28(5): 725-731. http://dx.doi. org/10.1590/S0100-67622004000500012.

Trugilho PF, Lima JT, de Pádua FA, Soragi L. C., Andrade CR. Deformação residual (DRL) e tangencial (DRT) em seis clones de Eucalyptus spp. Cerne 2006; 12(3): 279-286.

Vidaurre GB, Nutto L, França FJN, Braz RL, Watzlawick LF, Moulin JC. Tensão de crescimento no lenho de Eucalyptus benthamii e sua relação com características dendrométricas em diferentes espaçamentos. Floresta e Ambiente 2015; 22(3): 408-415. http://dx.doi.org/10.1590/2179-8087.044413. 